\title{
Geothermal Study of a Tailings Deposit: Frost Line Modelling and Comparison to Field Data
}

\author{
Roger Knutsson', Anne Tuomela ${ }^{2}$, Anssi Rauhala ${ }^{3}$, Sven Knutsson ${ }^{4}$ \\ and Jan Laue ${ }^{5}$
}

\begin{abstract}
Seasonal freezing and thawing can have significant effects on tailings management. Tailings delivery, depositional schemes and water treatment are examples of activities that must be dealt with extra concern in sub-zero temperatures. Changes in mechanical properties, drainage possibilities or embedded frozen tailings layers are effects that can arise in poorly managed facilities. To avoid such consequences, a good understanding of the seasonal effects on the tailings deposit is needed. To get a better understanding of the geothermal regime in tailings, this paper presents a case study with geothermal modelling performed for the Laiva tailings facility in Finland, where major seasonal freezing and thawing periods are present. Ground temperatures and frost lines were predicted via one-dimensional modelling using air temperatures and snow cover depths from adjacent weather stations, and basic soil properties from the facility. Simulated results were compared to data obtained from thermal instruments in the field. The snow cover and its estimated thermal properties were shown to have large influence on the results. The model was able to accurately predict the thermal regime measured in the field. Strong agreement was shown, both in terms of ground temperatures and frost front positions.
\end{abstract}

\footnotetext{
${ }^{1}$ Department of Civil, Environmental and Natural Resources Engineering Luleå University of Technology.

${ }^{2}$ Water Resources and Environmental Engineering Research Group University of Oulu.

${ }^{3}$ Water Resources and Environmental Engineering Research Group University of Oulu.

${ }^{4}$ Department of Civil, Environmental and Natural Resources Engineering Luleå University of Technology.

5 Department of Civil, Environmental and Natural Resources Engineering Luleå University of Technology.
} 
The methodology presented is useful for tailings management schemes in cold regions.

Keywords: Geothermal Monitoring, Geothermal Modelling, Tailings, Soil Temperature, Frost Tubes, Snow Cover.

\section{Introduction}

For tailings storage facilities in Arctic or subarctic climate winter conditions should be considered in the management of tailings. Seasonal freezing and thawing of deposited tailings have significant impact on the tailings deposit influencing changes in mechanical properties (Beier and Sego, 2009), drainage and consolidation possibilities (Proskin et al., 2010) and embedding of layers that remain frozen all year round (Nixon and Holl, 1998). All of these aspects must be considered in the stewardship of northerly located facilities. Optimising deposition schemes with respect to winter conditions (Caldwell et al., 2014; Knutsson et al. 2017a) are therefore important for successful management. With reliable predictions of the thermal regime associated with freezing and thawing, better understanding and improved stewardship can be reached for tailings facilities in cold regions.

Finland and Sweden are rich on mineral deposits. Many of the mines are located in the north with significant major seasonal freezing and thawing. Therefore freezing of pipes, impact on water balance and thaw weakening of frozen tailings are concerns in cold climate that must be dealt with in tailings management. There have also been indications of embedded permafrost layers in some facilities, even though there is no natural permafrost in the specific regions. To get a better understanding of the geothermal regime in tailings facilities, reliable predictions are needed. This paper presents a study of geothermal simulations and field monitoring of the tailings facility belonging to the Laiva gold mine, Finland.

The aim of the study is to evaluate the ability to predict thermal regimes in tailings with just very basic information available. Prediction is here conducted with a geothermal model, using easily accessible data such as air temperatures, snow depth cover and soil/tailings parameters as input. Predicted temperatures and frost front positions are compared with corresponding field data. Good agreement between simulation results and field data would validate the modelling methodology and confirm the ability to predict frozen areas. The method would then be useful for prediction of temperatures and frost lines in northerly located tailings facilities. 


\section{Method}

For this study, one-dimensional simulations were performed with a model developed by Knutsson et al. (2017b). The model simulates the geothermal regime in tailings. Inputs to the model are easily accessed from weather stations (air temperatures and snow depth cover) and tailings management operations (deposition rate and tailings properties).

\subsection{Case study - Laiva tailings facility}

Laiva is a gold mine owned by mining and exploration company Nordic Mines. It is located approximately $70 \mathrm{~km}$ south-west from city of Oulu (Figure 1, left). The Laiva mine produced gold between 2011 and 2014 and is currently inactive (Nordic Mines, 2014).

Tailings generated from the extraction processes were pumped approximately $7 \mathrm{~km}$ from the plant to a high compression thickener, located close to the tailings facility. The thickened tailings with estimated solids content of 65-70\% (by mass) were fed to the tailings facility (Regional State Administrative Agency of Northern Finland, 2016). An overview of the tailings storage facility is presented in Figure 1, right. Along the perimeter of the facility, embankment dams (class 2 dam in Finnish dam safety classification, Isomäki et al., 2012) confine the deposited tailings. Downstream the dams, ditches are used for catchment of seepage water. The tailings were deposited from three discharge points approximately $100 \mathrm{~m}$ from the northern dam. The discharge points can be seen as the white areas near the middle of the facility in Figure 1, where colors correspond to surface elevation.

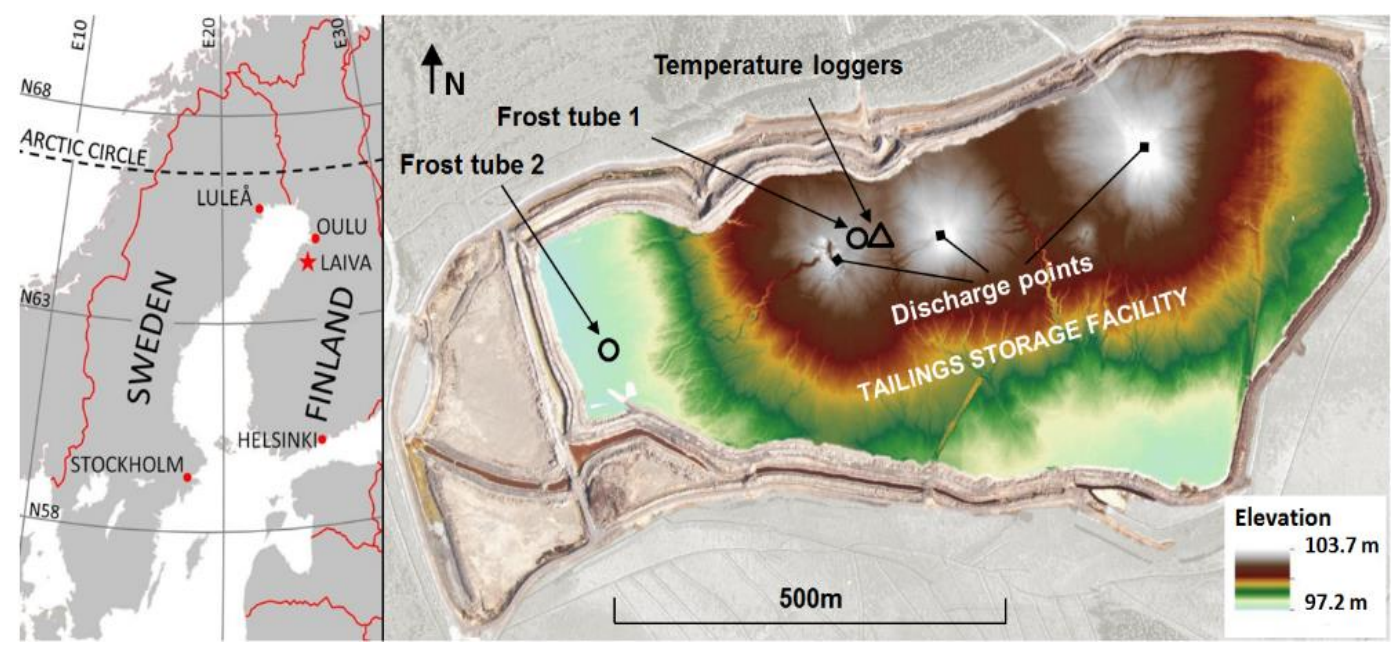

Figure 1: Left: Location of Laiva Mine (star). Right: Laiva tailings facility with locations of field instruments. 


\subsection{Thermal field data}

The thermal regime in the Laiva tailings facility is monitored by one set of temperature sensors and two frost tubes (also known as Gandahl frost depth indicator, Gandahl, 1963). For this study, air temperatures measured at a weather station of Finnish Meteorological Institute in the city of Raahe (FMI, 2017) were used. The weather station is located approximately $21 \mathrm{~km}$ west from the tailings facility. The temperatures might slightly differ compared to those in Laiva, but will not further be considered here.

The temperatures in the tailings deposit are measured with Onset HOBO UA-00108 Pendant temperature data loggers (Onset, 2017). A set of 11 loggers are attached to hollowed cavities in a plastic pipe with foam rubber insulation and plastic outer casing so that each logger rests in an insulated cavity. A tight-fitting hole was drilled into the tailings for the logger unit installation. The sensors are located approximately at depths of $0.1 \mathrm{~m}, 0.2 \mathrm{~m}, 0.4 \mathrm{~m}$, and so forth with an interval of 0.2 $\mathrm{m}$ down to $2 \mathrm{~m}$ below the tailings surface. The set of sensors are presented in Figure 2.

With frost depth indicators, the position of the zero-isotherm is measured. It is a casing containing removable, transparent inner tube filled with a methylene blue solution which change colour upon freezing. The zero-isotherm is noticed as the distance between the ground surface and the boundary between white ice and unfrozen blue water in the inner pipe. To follow the frost penetration, measurements are taken at regular intervals during the winter by lifting the rod up and notice the boundary between ice and not frozen blue water. A frost tube in Laiva is presented in Figure 2.

Frost depth indicators (tubes) are easy to handle and well-aimed for measuring frost penetration (Iwata et al., 2012). The accuracy in measuring frost depth is about $5 \mathrm{~mm}$ (Andersland and Ladanyi, 2004). However, frost tubes don't provide any information on the temperature profile. Also, frost tubes are not usable for measuring thaw penetration compared to measurements with temperature sensors (Iwata et al., 2012). For temperature sensors inaccuracies in detecting phase changes in the soil are highlighted by Sharratt and McCool (2005). Therefore, frost tubes and temperature sensors are complementary and the instruments provide good information on the thermal regime in the soil.

The placement of the instruments in the Laiva tailings facility is also presented in Figure 1, right. Frost tube 1 and the temperature sensors are located in the middle of the facility approximately $100 \mathrm{~m}$ south of the northern dam. They are located close to one of the former tailings discharge points (highest elevation). Frost tube 2 is placed approximately $100 \mathrm{~m}$ east of the western dam, most far away from the former tailings discharge points (the lowest elevation).

In Laiva, the winters are associated with a snow cover which acts as an insulating layer on the ground surface. The depth of the snow cover was represented here by snow measurements conducted by the Finnish Meteorological Institute in the 
municipality of Siikajoki (FMI, 2017). Siikajoki is located approximately $25 \mathrm{~km}$ north-east of the Laiva tailings facility, and $33 \mathrm{~km}$ east of the weather station providing air temperatures. The snow depths with time (winter 2016-2017) are given in Figure 3 (scale on right axis).

The temperature sensors were installed May 28, 2016 and temperatures are logged automatically every fourth hour. The specifications indicate an accuracy of \pm 0.53 ${ }^{\circ} \mathrm{C}$ and a resolution of $0.14{ }^{\circ} \mathrm{C}$ for the sensors. Measured temperatures with time are presented in Figure 3, where the different curves correspond to sensors at different depths.

For the summer conditions (left part in Figure 3), shallow placed sensors show temperatures that directly change as a response to the air temperatures (black curve). For the sensors at larger depths, the temperatures are changing with time, but the response to air temperatures is slower. The yearly temperature variation is therefore lower at larger depths. For the sensor located at $0.1 \mathrm{~m}$ depth, the agreement with air temperatures is strong during the summer period. At the beginning of winter (November), the agreement is lost. Despite significant drops in the air temperature, the temperature at the sensor near tailings surface remains close to $1{ }^{\circ} \mathrm{C}$. This is due to the effects of the snow cover, but also to the phase change due to freezing in the tailings. To the right in Figure 3, the strong agreement with air temperatures is again seen. This is the period when the tailings are thawed, and temperatures above zero are measured.

The readings from the frost tubes are taken once a week by staff at the Laiva mine. The results of these measurements are presented in Figure 4. The zero-isotherm from temperature sensors, interpreted with linear interpolation, is also given in Figure 4. Frost penetration starts in the beginning of November. A rapid frost penetration took place in the beginning of the winter, followed by stagnated penetration between mid-November and early January. From January, frost penetration rate was increased and reached the maximum frost depth at the end of the winter (May). Maximum frost depth $(0.49 \mathrm{~m})$ was seen in frost tube 1 . No data is available for the frost tubes later than April 12. In the beginning of May, the temperature sensors indicated thawing, lasting for one week until all tailings were thawed.

Although similar trends are found for all instruments, comp. Figure 4, some differences are noticed. The difference in the results from frost tube 1 and tube 2 can be attributed to their different locations in the facility. Despite tailings thickening, some sorting of grains is probable due to hydraulic tailings deposition. The area in which frost tube 1 is located, is expected to contain slightly denser and/or drier tailings than that in the area where frost tube 2 is located. Dry tailings would therefore allow faster and deeper frost penetration compared to wet tailings. This can be recognised in the results (Figure 4). Based on location, interpreted frost depths from temperature sensors and frost tube 1 should be identical. But major differences are seen in mid-December where the temperature sensors indicate the profile to be fully thawed, which is not seen by the frost tubes. Since frost tubes are unsuited during thaw (Iwata et al. 2012), the temperature measurements are more 
reliable for this time period.

Further differences in frost depths are noticed in March/April. The frost depth derived from temperature sensors stabilizes just above the depth of $0.4 \mathrm{~m}$, whereas the frost depth obtained from the tube continue to increase. The temperature sensor located at $0.4 \mathrm{~m}$ depth mal-functioned and did not measure sub-zero temperatures until the first week of May and this is likely the reason behind the observed differences during this time period.

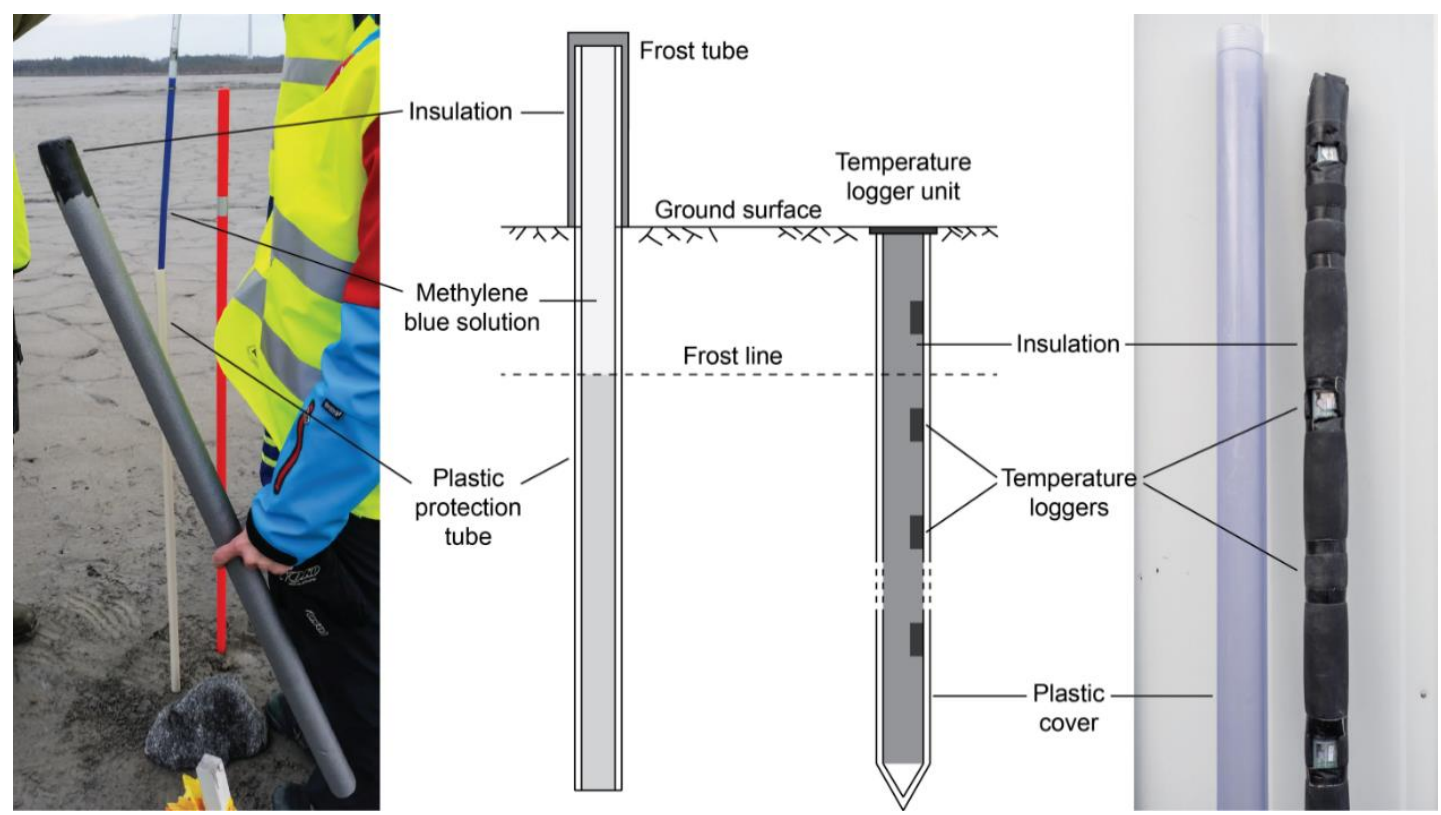

Figure 2: Left: Frost depth measurements via frost tube. Right: Temperature loggers. 


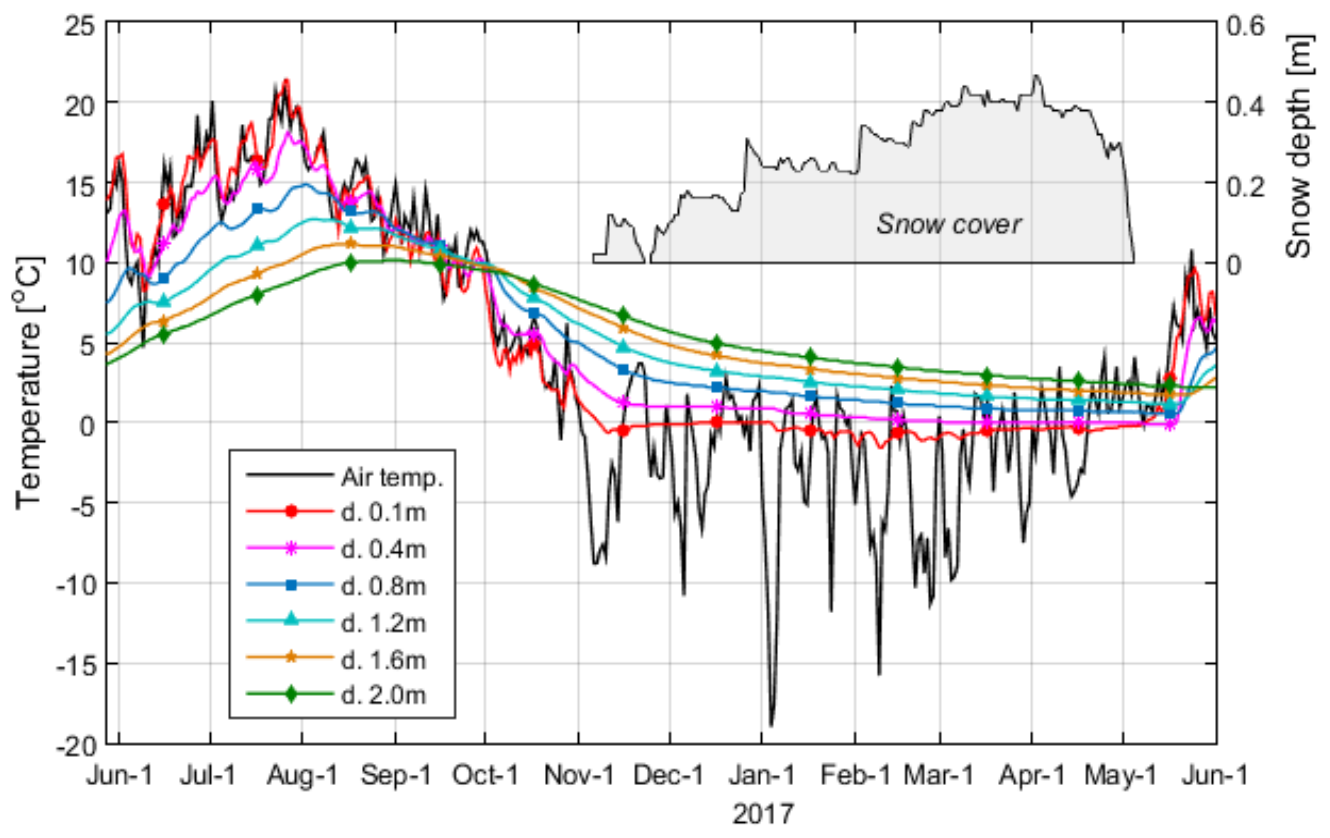

Figure 3: Left axis: Air and ground temperatures with time (logger depths in legend). Right axis: Depth of snow cover with time.

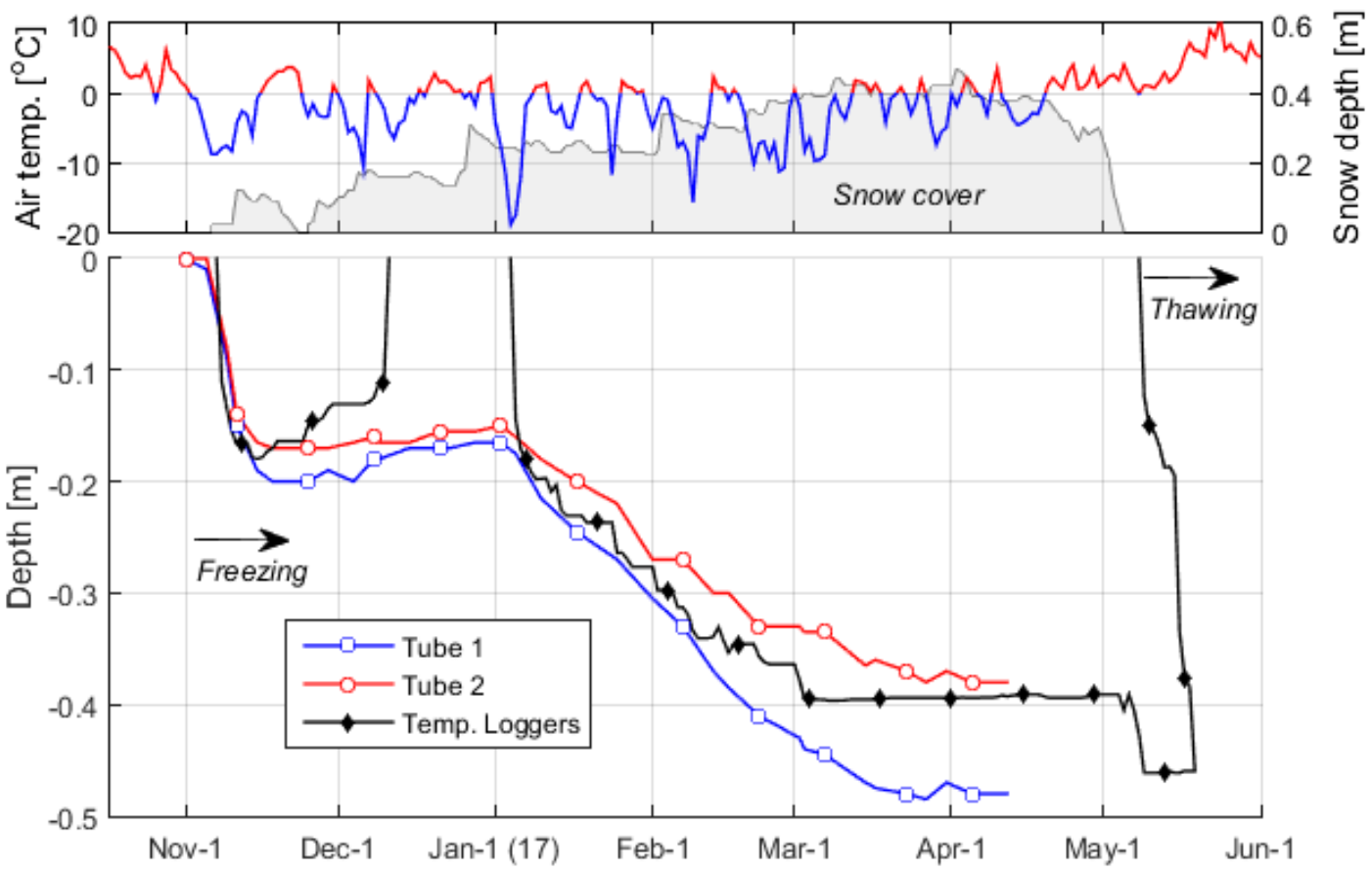

Figure 4: Winter 2016-2017. Upper: Air temperatures and snow cover depth.

Lower: Measured frost depths from frost tubes, and interpreted zeroisotherm from temperature loggers. 


\subsection{Tailings properties}

Tailings were sampled around the facility. Most laboratory work was performed on samples taken close to one of the discharge points (the middle "cone" in Figure 1). The tailings were classified as sandy clayey silt (approx. $65 \%$ fines). Average values of degree of saturation $\left(S_{\mathrm{r}}\right)$, dry density $\left(\rho_{\mathrm{d}}\right)$, gravimetric water content $(\mathrm{w})$ and particle density $\left(\rho_{\mathrm{s}}\right)$ are given in Table 1 . The quartz content $(\mathrm{q})$ in the ore is estimated to range between 56-59 \% (Finnäs, 2017). These values were used for estimating thermal properties of the tailings.

\subsection{Simulations}

\subsubsection{Model input}

The aim was to capture the thermal regime in the tailings, which was measured at site. For this, one-dimensional simulations were performed with a model developed by Knutsson et al. (2017b). The model simulates the geothermal regime in tailings with possibility to include tailings deposition (change of tailings height with time). At the tailings surface, the temperature is changed with time according to ambient air temperatures. Air temperatures, tailings height with time, tailings properties and ratios between ground surface temperatures and air temperatures ( $\mathrm{n}$-factors) are given as input to the model (Knutsson et al., 2017b). For this study, no tailings deposition was included in the simulations since no deposition is taking place. The thermal effects of snow cover were however taken into consideration.

The thermal properties for the tailings were calculated according to Andersland and Ladanyi (2004) based on the measured soil properties. The thermal properties are summarised in Table 1.

Table 1: Tailings properties and their calculated thermal properties.

\begin{tabular}{|l|c|c|c|c|c|}
\hline \multirow{2}{*}{ Input } & \multicolumn{2}{|c|}{ Thermal conductivity, $\boldsymbol{k}$} & \multicolumn{2}{c|}{ Vol. heat capacity, $\mathbf{C}_{\text {vol }}$} & \multirow{2}{*}{ Vol. latent heat, $\boldsymbol{L}$} \\
\cline { 2 - 5 } & Unfrozen & Frozen & Unfrozen & Frozen & \\
\hline $\mathrm{S}_{\mathrm{r}}=95 \%$ & & & & & \\
$\rho_{\mathrm{d}}=1.77 \mathrm{t} / \mathrm{m}^{3}$ & & & & \\
$\mathrm{w}=19.4 \%$ & 2.03 & 3.25 & $2.79 \cdot 10^{6}$ & $2.06 \cdot 10^{6}$ & \\
$\rho_{\mathrm{s}}=2.77 \mathrm{t} / \mathrm{m}^{3}$ & $\mathrm{~W} /\left(\mathrm{m} \cdot{ }^{\circ} \mathrm{C}\right)$ & $\mathrm{W} /\left(\mathrm{m} \cdot{ }^{\circ} \mathrm{C}\right)$ & $\mathrm{J} /\left(\mathrm{m}^{3} \cdot{ }^{\circ} \mathrm{C}\right)$ & $\mathrm{J} /\left(\mathrm{m}^{3} \cdot{ }^{\circ} \mathrm{C}\right)$ & \\
$\mathrm{q}=57.5 \%$ & & & & & \\
\hline
\end{tabular}

The simulations were performed for a $10 \mathrm{~m}$ thick tailings profile. The element size was set to $0.01 \mathrm{~m}$ (elements in which temperatures were calculated). Air temperatures from the weather station in Raahe Lapaluoto (FMI, 2017) were imported to the model. The yearly average air temperature was calculated to $3.85^{\circ} \mathrm{C}$, and was used as a fixed temperature in the bottom of the simulated tailings profile.

The ratio between ground surface temperature and air temperature, the n-factor after Andersland and Ladanyi, was chosen to be 1 . This value is in agreement with the summer period (Figure 3), where there is strong agreement between air 
temperatures and temperatures at $0.1 \mathrm{~m}$ depth. Although less information is available regarding the $n$-factor in sub-zero temperatures (since it is affected by snow), it was set in this study to 1 during winter time well.

Available field data is restricted to the period from May 28, 2016 and onwards, see Figure 3 and Figure 5. In order to estimate the temperature regime for the beginning of this period, simulations were performed for four preceding years with static tailings surface (starting in October 2012). The air temperatures used for this simulation are shown in Figure 5. The temperature profile in October 2012 was set to $3.85{ }^{\circ} \mathrm{C}$ throughout the tailings profile. The simulated temperature profile for May 28 (2016) is presented in Figure 6 (dashed line with open markers), and show strong agreement with the measured temperatures at this day (solid lines with filled markers). In Figure 6 it is also clear that simulated temperatures at large depths, are barely influenced by the surface temperatures. At a depth of $7 \mathrm{~m}$, the temperatures have a constant value $3.85^{\circ} \mathrm{C}$, which is the boundary value set at the bottom of the profile.

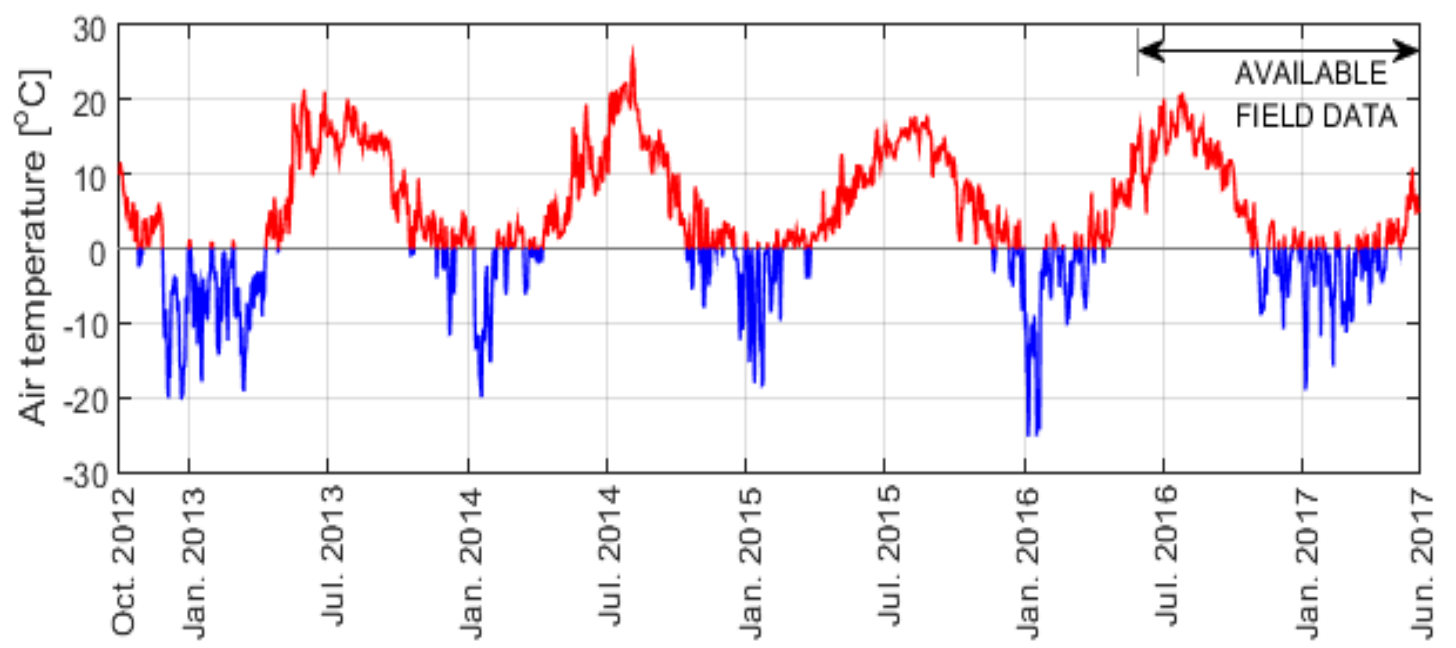

Figure 5: Air temperatures used in the simulations (Oct.1 2012 to Jun.1 2017); from Raahe Lapaluoto weather station (FMI 2017). 


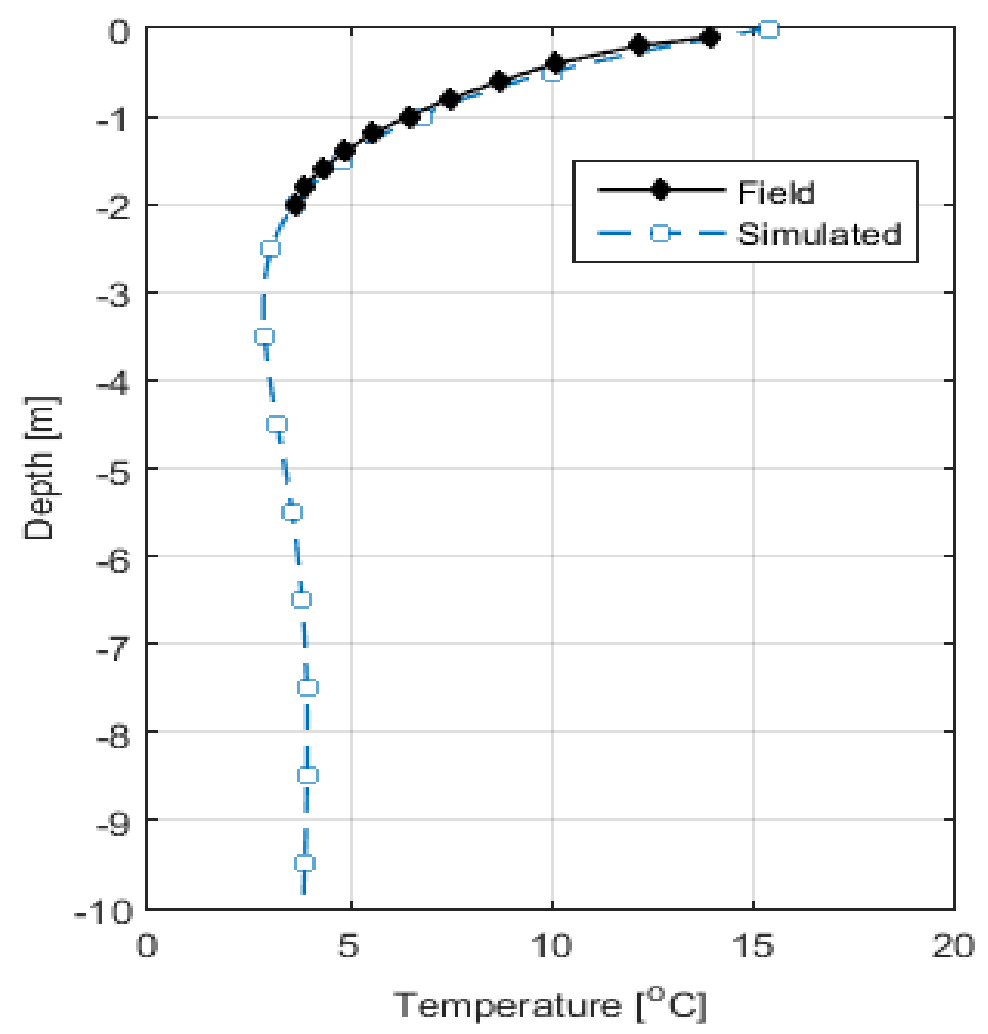

Figure 6: Field (measured at site) and simulated temperature profiles, May 282016.

\subsubsection{Snow cover}

The impact of snow on the thermal regime in the tailings was modelled by a thermal resistivity approach. The snow cover was in the model interpreted as a thermal resistance on the tailings surface, affecting the heat flow in and out of the deposit. Both snow cover and air temperatures (with time) are given as independent input to the model, while and possible melting of snow due to warm air temperatures is not considered. Melting is indirectly taken into account by the decreased snow cover, which is measured. A drawback with this method is that no temperatures in the snowpack are calculated but the simplified approach is useful for further modelling when tailings deposition must be taken into consideration. Such interaction between fresh tailings and snow (or snow fall) is discussed by Nixon and Holl (1998), and has not been simulated. By considering the snow as a surface resistance with time, this type of modelling is facilitated.

The snow density profile was estimated by linear interpolation according to Figure $7\left(\right.$ a). New snow at the top was given a minimum density value $\left(\rho_{\min }\right)$, and in the bottom of the snow pack the density increased linearly from the minimum value up to a maximum value $\left(\rho_{\max }\right)$. The maximum density was reached at the day when maximum snow cover was measured. The snow density profile was correspondingly interpolated between the values at the surface and the bottom. After the maximum snow cover was reached, the density in the bottom was set constant 
to the maximum density value and the density at the surface was linearly increased from the minimum to the maximum value. The snow density variation, calculated for the measured snow depth, is presented in Figure 7(b). Light colours correspond to low densities and dark colours correspond to higher densities.

For this study, three simulation cases were performed where the minimum snow density was altered, i.e. 200, 400 and $600 \mathrm{~kg} / \mathrm{m}^{3}$ respectively. Maximum snow density was for all cases set to $600 \mathrm{~kg} / \mathrm{m}^{3}$. For the case with minimum density of $600 \mathrm{~kg} / \mathrm{m}^{3}$, the snow density was obviously constant $600 \mathrm{~kg} / \mathrm{m}^{3}$ in time and depth. Based on calculated density, the thermal conductivity was calculated with Eq. (1) according to Sturm et al. (1997).

$k=0.138-1.01 \frac{\rho}{1000}+3.233\left(\frac{\rho}{1000}\right)^{2}$

limits: $156 \mathrm{~kg} / \mathrm{m}^{3} \leq \rho \leq 600 \mathrm{~kg} / \mathrm{m}^{3}$

Where: $\mathrm{k}$ thermal conductivity of snow $\left[\mathrm{W} /\left(\mathrm{m} \cdot{ }^{\circ} \mathrm{C}\right)\right]$

$\rho$ snow density $\left[\mathrm{kg} / \mathrm{m}^{3}\right]$

Average thermal conductivities in the snow pack are presented in Figure 7(c). It is clear that for the case with low snow density $\left(\rho_{\min } 200 \mathrm{~kg} / \mathrm{m}^{3}\right)$ the thermal conductivity gets lower than for the cases with higher densities.

The thermal resistivity of the snow pack was then calculated as the integral of the inverse of thermal conductivity, see Eq. (2).

$R(t)=\int_{0}^{\operatorname{snowdepth}(t)} \frac{1}{k(z, t)} d z$

Where: $\mathrm{R}$ thermal resistivity $\left[\mathrm{m}^{2 \circ} \mathrm{C} / \mathrm{W}\right]$

The thermal resistivity with time, for the different simulation cases (Figure 7(d)), increases with decreasing snow density. For the special case with constant density $600 \mathrm{~kg} / \mathrm{m}^{3}$ the thermal resistivity corresponds to the snow depth divided by the thermal conductivity. The resistivity values presented in Figure 7(d) were used in the simulations, acting as the thermal resistivity on the tailings surface.

In addition to the three simulations described, a fourth case without snow cover was also simulated. 
a)

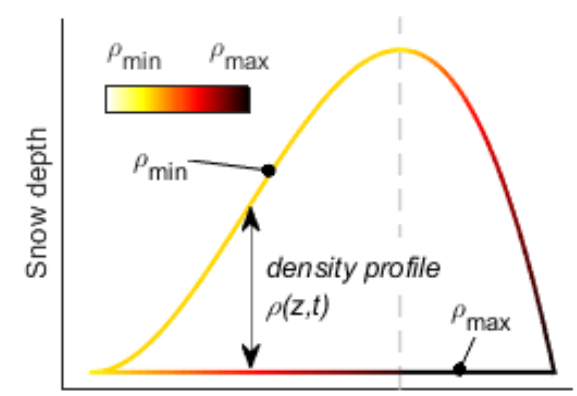

c)

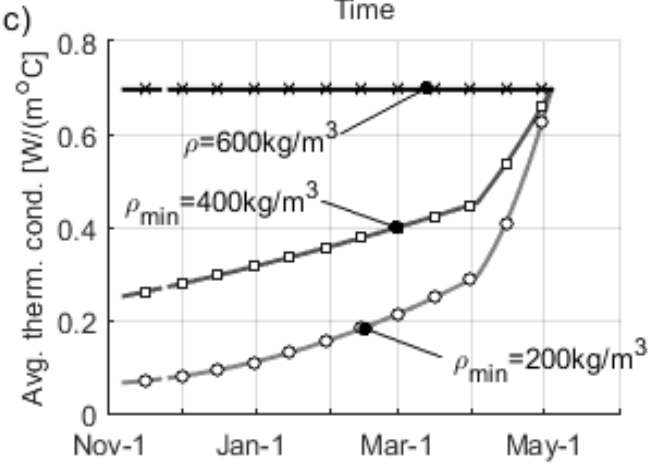

b)

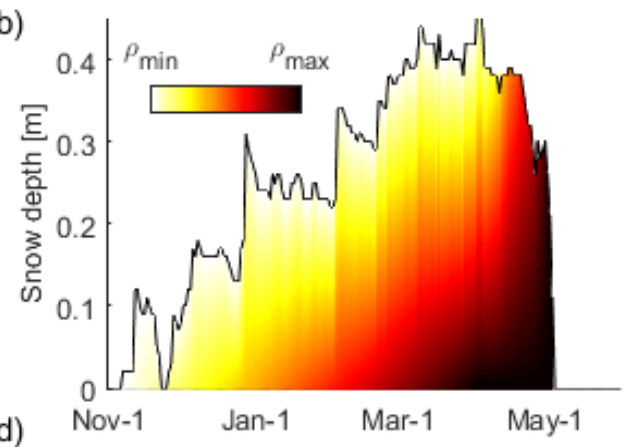

d)

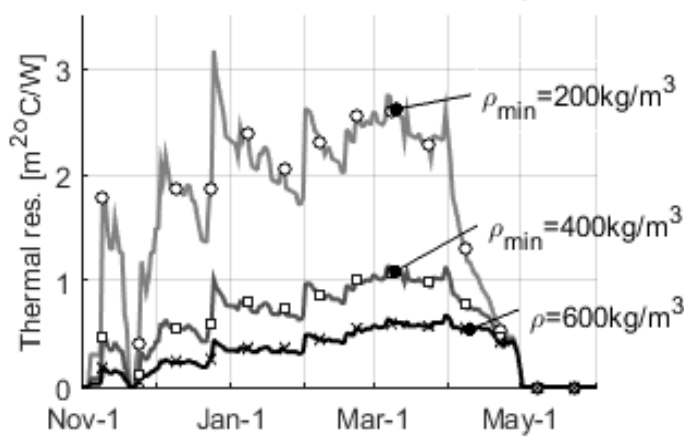

Figure 7: a) Estimation of snow density (schematic).

b) Calculated density variation in measured snow depth.

c) Calculated average thermal conductivity in snow pack.

d) Calculated thermal resistivity of snow for three simulation scenarios.

\section{Results}

Measured and simulated temperatures for depths of $0.1 \mathrm{~m}, 1 \mathrm{~m}$ and $2 \mathrm{~m}$, are shown in Figure 8. Solid lines correspond to the measured (field) temperatures, and dashed lines to simulated temperatures with minimum snow density $400 \mathrm{~kg} / \mathrm{m}^{3}$. In Figure 8 , the year is divided into three subplots, $\mathrm{a}, \mathrm{b}$ and $\mathrm{c}$ corresponding to different time periods.

For the summer period (May 28th-October 1st), Figure 8(a), there is strong agreement between simulated and field temperatures. The curves of temperatures versus time are nearly identical. Shallow depths in the tailings are more sensitive to changes in the air temperature and this is well captured by the simulations.

For the winter period (October 1st-February 1st), Figure 8(b), a deviation is noticed between simulated and field data. The difference was introduced during the first two weeks of November, where simulated temperatures at $1 \mathrm{~m}$ and $2 \mathrm{~m}$ depths got approximately $1.5^{\circ} \mathrm{C}$ colder than what is seen in the field data (see dashed ellipse). For the rest of the simulated period, the difference remained nearly constant (curves are nearly parallel to each other). For $0.1 \mathrm{~m}$ depth, larger deviation is seen in early November, but for the rest of the winter the temperature is close to $1{ }^{\circ} \mathrm{C}$ in both field and simulated data, see Figure 8(c). 
To facilitate comparison between simulated and field data, the frost and thaw depths with time are presented in Figure 9. The simulated zero-isotherm is presented as the dashed line, where the lightly shaded area corresponds to frozen tailings. The abovementioned deviation between the simulated and observed temperatures in the beginning of November is also reflected in the simulated frost depth. The simulation indicated rapid frost penetration reaching a depth of $0.33 \mathrm{~m}$ in mid-November, whereas the measured frost depth was between 0.17 and $0.2 \mathrm{~m}$ from field data (see dashed ellipse). After some thawing, both from above and below, strong agreement to frost depths obtained from Frost tube 1 was seen from approximately February 1 onwards. The maximum frost depth, and the time when all tailings were fully thawed, was also simulated accurately.

Figure 9 shows the results for the simulations without snow and with altered snow properties. The zero-isotherm according to the temperature sensors is drawn for comparison. Compared to the simulation with minimum snow density of $400 \mathrm{~kg} / \mathrm{m} 3$, the simulation with a lower minimum density of $200 \mathrm{~kg} / \mathrm{m}^{3}$ resulted in smaller frost depths, and a constant density of $600 \mathrm{~kg} / \mathrm{m}^{3}$ resulted in larger frost depths. Largest frost depths are clearly seen for the simulations without any snow cover, which was expected due to the absence of surface resistivity.

In early November (see dashed ellipse in Figure 9), all simulations indicate rapid frost penetration. For the three days just before the snow appeared, approximately $0.15 \mathrm{~m}$ of frost penetration has been calculated in all simulations. This corresponds well with obtained field data, but it appears approximately one week later in field. The rapid frost penetration in the simulations is due to absence of snow at these initial winter days. When the snow arrived, the frost penetration started to differ between the simulations and the results depend on the assumed snow properties. For the lower minimum density simulation $\left(\rho_{\min } 200 \mathrm{~kg} / \mathrm{m}^{3}\right)$, the generated frost depth in mid-November was larger than during the rest of the winter under same circumstances.

In this study air temperatures and snow data were obtained from two different locations (33 km apart), 21 and $25 \mathrm{~km}$ from the tailings facility respectively. Local variations between the sites, e.g. slightly higher temperatures and/or earlier snow arrival, are therefore unknown. Such variations can explain why the simulated and observed values deviate in the beginning of the winter. With earlier snow or slightly higher air temperatures during the first days of November, the simulations would most probably show stronger agreement to the field data. 

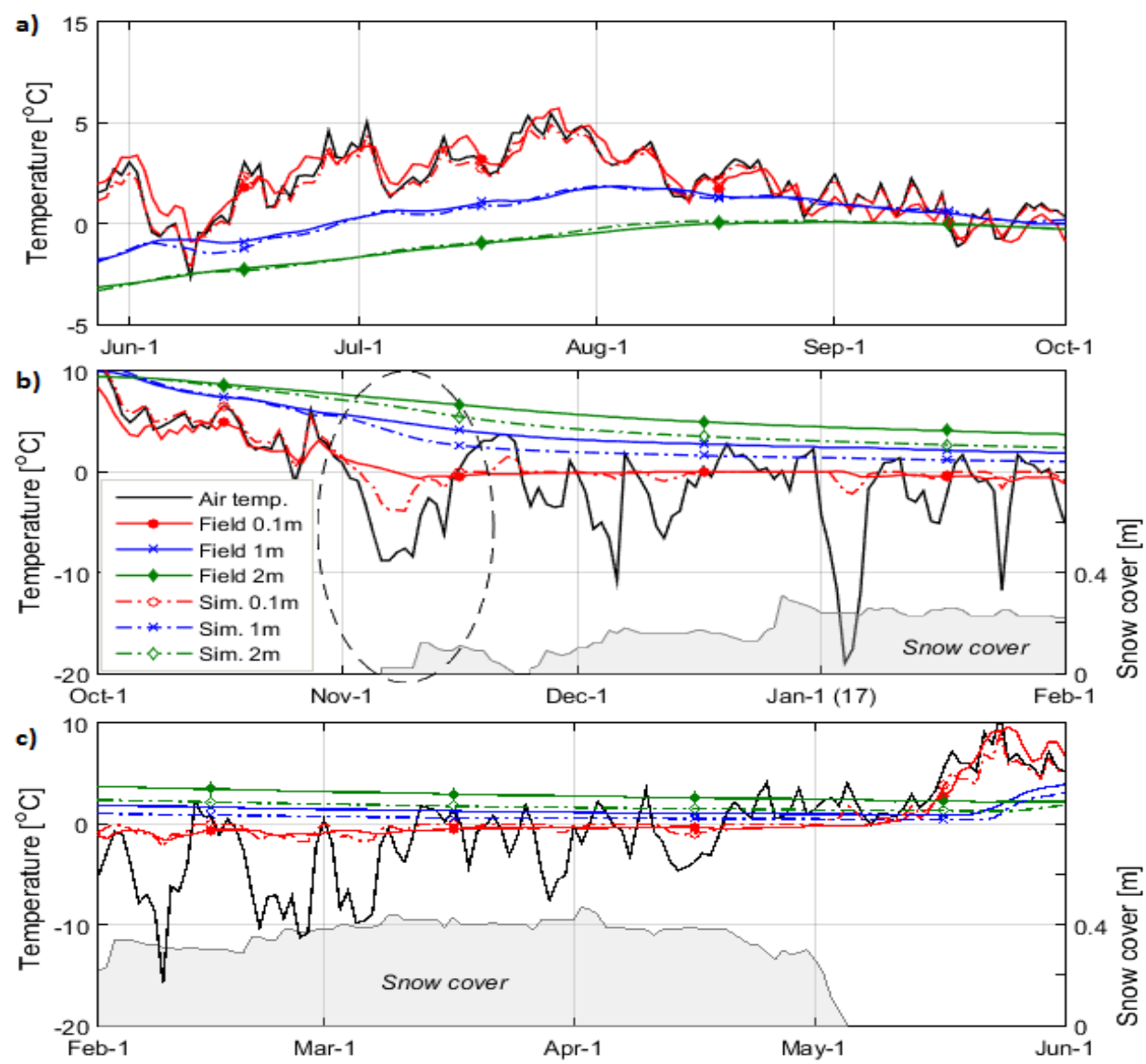

Figure 8: Field and simulated temperatures from May 282016 till June 1 2017. Dashed ellipse indicates the largest deviation between field and simulated data. 


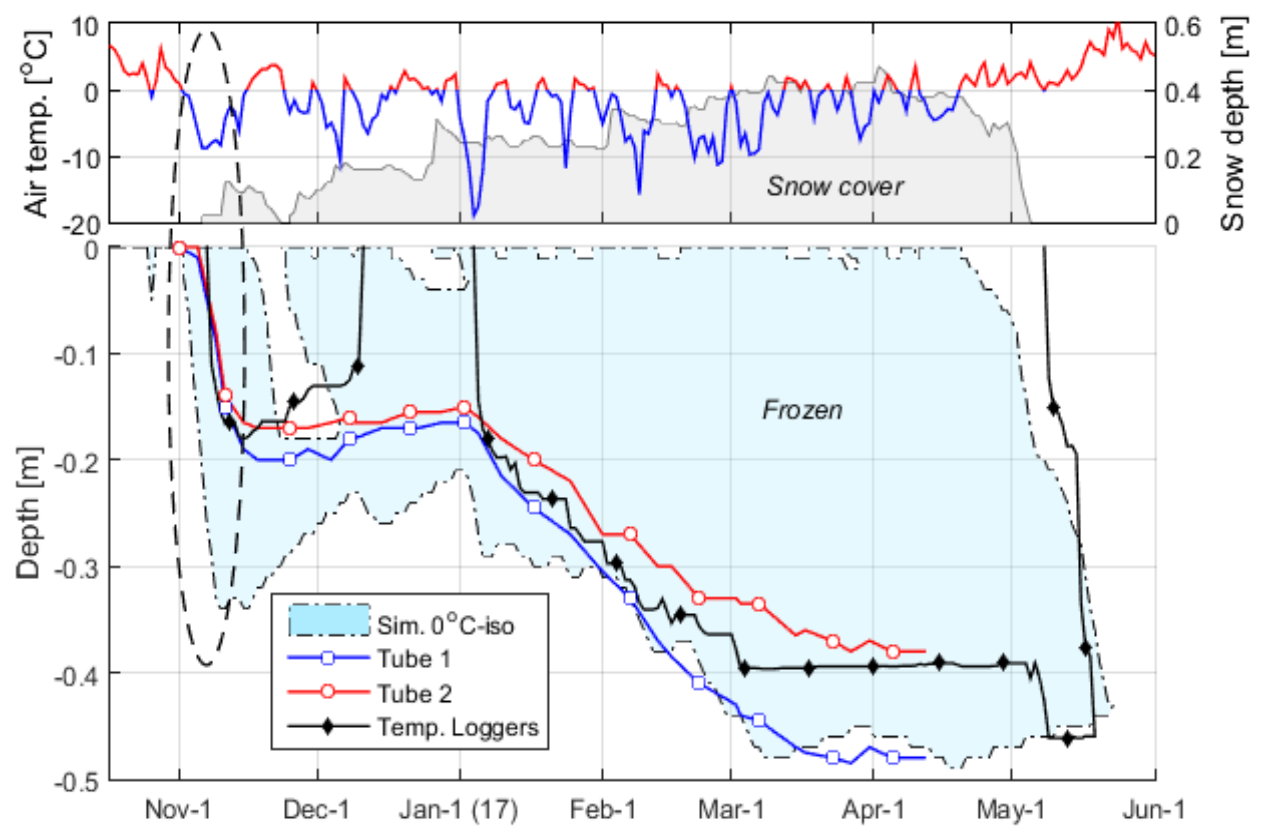

Figure 9: Zero-isotherms for simulations with different snow properties. Upper: Air temperatures and snow cover. Lower: Field and simulated zeroisotherms. Dashed ellipse indicates the largest deviation between field and simulated data.

\section{Summary and Conclusions}

In this study, geothermal simulations were performed and compared with measurements from the field. The input data to the geothermal simulation were taken from weather stations (air temperatures and snow cover) and tailings data from laboratory testing. Simulations were performed based on the methodology described by Knutsson et al. (2017b) and extended with the possibility to account for a snow cover.

From measured snow depth, its thermal resistivity was estimated and used as a surface resistivity on the tailings. This was performed by estimated density and its correlation to thermal conductivity (Sturm et al., 1997). The surface resistivity affects the heat flux in or out of the tailings. The method provides good information of the impact of snow on frost depths but no information of temperatures in the snow is obtained. Air temperatures and snow depths are given as independent input to the model, while local details like potential snow fall, snow melt, or refreezing of snow due to ambient air temperatures are not considered.

The simulation with low snow density was, as expected, resulting in the smallest frost depths. Higher snow density was correspondingly resulting in larger frost depths. Largest frost depths were seen for the simulation without snow. 
Strongest agreement to field measurements was observed for the simulation with minimum snow density of $400 \mathrm{~kg} / \mathrm{m}^{3}$. This was both the case for temperatures and frost depth versus time. The simulated temperatures for the summer period were nearly identical to the values observed in field measurements. Despite the large influence from snow parameters, the model's ability to predict the thermal regime in tailings is confirmed. Similar modelling is therefore recommended for predicting the thermal regime in tailings facilities with seasonal freezing and thawing.

An obvious difference between simulations and field data, is the modelled rapid frost penetration in early November that was not measured in field. Considering the strong agreement for the rest of the simulated time period, the simulated error is most likely due to the variation of snow cover between the station and the actual location of the mine. The snow cover was shown to have large influence on the thermal regime in the ground, and its role during the first days of freezing is significant. Another potential explanation for the variations might be effects due to chemical reactions, salinity or moisture transfer, which have not been considered in the simulation. Despite using very basic information as input data, the strong agreement to field data validates the model's ability and robustness to predict the thermal regime in tailings.

Although a simple approach was used for treating the insulating effects of snow, the presented methodology seems promising for further modelling of tailings. In particular, its simplicity would facilitate its use in combination with tailings deposition.

Acknowledgment: Financial supports to this study were given by Luleå University of Technology and Oulu University, and are highly acknowledged. The study was also partly funded by the Interreg Nord 2014-2020 program (RESEM, http://www.oulu.fi/water/resem), K. H. Renlunds foundation, and Tauno Tönning foundation. We appreciate the help of laboratory technicians Tuomo Reinikka and Tuomo Pitkänen, and Master student Jenna Hietala at the University of Oulu. We are also grateful for the cooperation with the personnel at the Laiva mine. 


\section{References}

[1] Andersland, B. and Ladanyi, B. (2004) Frozen Ground Engineering, 2nd ed. American Society of Civil Engineers and John Wiley \& Sons Inc., Hoboken, New Jersey.

[2] Beier, N. and Sego, D. (2009). Cyclic freeze-thaw to enhance the stability of coal tailings. Cold Regions Science and Technology, Vol. 55, pp 278-285.

[3] Caldwell, J., Revington, A., McPhail, G. and Charlebois, L. (2014). Optimised seasonal deposition for successful management of treated mature fine tailings. Proc. 17th International Seminar on Paste and Thickened Tailings, PASTE 2014, Canada.

[4] Finnäs, P. (2017) Personal communication. May 31.

[5] FMI (2017) - Air temperatures Raahe Lapaluoto (Station ID 101785) and Snow cover depth Siikajoki Ruukki (Station ID 101787). Finnish Meteorological Institute. http://en.ilmatieteenlaitos.fi/ (retrieved 2017-06-16).

[6] Gandahl, R. (1963). Determination of the ground frost line by means of a simple type of frost depth indicator. Report 30A. The National Swedish Road Research Institute, Stockholm.

[7] Isomäki, E., Maijala, T., Sulkakoski, M., and Torkkel, M. (2012). Dam Safety Guide. Report 89, Centre for Economic Development, Transport and the Environment.

[8] Iwata Y., Hirota T., Suzuki T. and Kuwao, K. (2012). Comparison of soil frost and thaw depths measured using frost tubes and other methods. Cold Regions Science and Technology, Vol. 71, pp 111-117.

[9] Knutsson, R., Viklander, P., Knutsson, S. and Laue, J. (2017a). How to avoid permafrost while depositing tailings in cold climate. Submitted to Cold Regions Science and Technology.

[10] Knutsson, R., Viklander, P., Knutsson, S. and Laue, J. (2017b). Geothermal study to explain man-made permafrost in tailings with raised surface. Submitted to Environmental Earth Sciences.

[11] Nixon, J.F. and Holl, N. (1998). Geothermal modelling of soil or mine tailings with concurrent freezing and deposition. Canadian Geotechnical Journal, Vol 35 , pp 234-250.

[12] Nordic mines (2014). Press release 10 April. http://www.nordicmines.com/en/press-releases/ (retrieved 2017-10-28).

[13] Onset (2017). http://www.onsetcomp.com/ (retrieved 2017-11-25).

[14] Proskin, S., Sego, M., and Alostaz, M. (2010). Freeze-thaw and consolidation tests on Suncor mature fine tailings (MFT). Cold Regions Science and Technology, Vol. 63, pp 110-120.

[15] Regional State Administrative Agency of Northern Finland (2016) [Decision for Environmental Permit], 17 June 2016. "Laivakankaan kaivoksen ympäristöluvan muuttaminen koskien rikastushiekan A varastoaluetta ja toiminnan aloittamislupa, Raahe, permit number 76/2016/1", Decision reference number PSAVI/126/04.08/2013. [In Finnish]. 
[16] Sharratt, B. and McCool, D. (2005). Micrometeorology in Agricultural Systems. Chapter 8, Frost depth, American Society of Agronomy, Inc., Madison, Wisconsin.

[17] Sturm, M., Holmgren, J., König, M. and Morris, K. (1997). The thermal conductivity of seasonal snow. Journal of Glaciology, Vol. 43, pp 26-41. 